\title{
Deciding the future of Uganda's tropical forests
}

\author{
Gary M. Tabor, Andrew D. Johns and John M. Kasenene
}

The FFPS has been involved for some time in conservation activities in the diminishing montane forests of east-central Africa. These montane forests form an upper sector of an even more endangered medium-altitude forest formation. Throughout their distribution, medium-altitude forests have been extensively disturbed by ever-increasing human activities. Extensive areas remain only in eastern Zaire, where there ststus is uncertain, and in Uganda. The Ugandan forests are now the focus of a major internationally financed development programme.

Tropical moist forests cover less than 10 per cent of the Earth's land surface, but may contain the world's richest and most complex ecosystems. They are rivalled only by coral reefs, which actually cover a much smaller area. Tropical rain forests receive a disproportionate amount of publicity these days; perhaps deservingly. International concern has, however, focused on some of the largest remaining natural forest areas, particularly the Amazon Basin and Borneo. Much less concern has been generated for the rare and more vulnerable tropical forest types.

There are quite a number of these. They share the trait that few people have ever heard of them. The tropical dry forest of Mesoamerica is one example; this is so badly affected that scientists are reduced to trying to recreate it. Another example would be the higher-altitude forests of east-central Africa. These are still in existence, but are badly fragmented. Many fragments may no longer be considered viable units. These forests are currently the focus of an increasingly heated debate. Are they worth saving? If so, how?

\section{Defining the forests}

From the Pleistocene until comparatively recently, higher-altitude tropical forests covered much of what is now southern and western Uganda, extending into eastern Zaire,
Rwanda and Burundi. They were bordered in the west by lowland rain forest and on other sides by wooded savannah and by Lake Victoria. Now these forests are reduced to isolated fragments, the result of heavy deforestation through human activity (Hamilton, 1984) (Figure 1).

Higher-altitude tropical forests are divided into two basic types: medium-altitude and montane forests. The distinction is unclear, however. Both are often regarded as 'transition forests' between lowland rain forest and

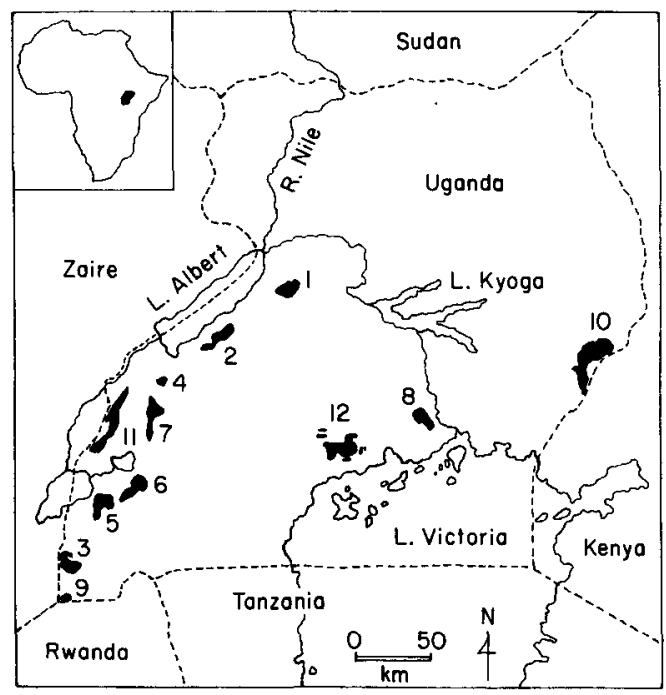

Figure 1. Principal medium-altitude forest areas remaining in Uganda (adapted from Struhsaker, 1987). Numbers refer to Table 1. 
non-forest montane and alpine vegetation (Hamilton, 1984). Nevertheless, their plant and animal assemblages are quite distinct. Although they share many species with loweror higher-altitude vegetation, they also contain a number of unique species, including some of the world's rarest and least known (for example, the Kibale ground thrush Zoothera kibalensis is known from only two specimens collected in 1966 from a single 560$\mathrm{sq}-\mathrm{km}$ forest isolate).

Throughout their former historical distribution, the medium-altitude forests (those generally between 1130 and $1850 \mathrm{~m}$ above sea level) have been severely reduced in size. Montane forests, although less suitable for conversion to agricultural small-holdings, have fared little better. Reasonably sized blocks of mediumaltitude forests remain in Zaire: perhaps 1600 $\mathrm{sq} \mathrm{km}$ in the Itombwe region. In much of this part of Zaire, however, remaining forests face tremendously high human popualtion pressures and are poorly managed (d'Huart, 1989). In Uganda some $5000 \mathrm{sq} \mathrm{km}$ remain, although the largest surviving block covers only 523 sq $\mathrm{km}$. Much of the remaining forest is disturbed to some extent, the result of past management strategies, and of encroachment at times of social unrest. New management strategies are now being formulated. The fate of the entire forest ecosystem of Uganda, not just a part of it, is likely to be decided within the next five years.

\section{The debate}

In January 1988 the World Bank committed around \$US33.5 million to various projects concerned with the rehabilitation of the forestry sector in Uganda. The programme emphasized re-establishment of self-sufficiency in fuelwood (including charcoal production), planting of exotic softwoods and timber harvesting from remaining forests.

The point was made that World Bank involvement in natural forest harvesting was out of line with their own Wildlands Policy (World Bank, 1986; Ledec and Goodland, 1987), designed to avoid eliminating remaining natural areas. A high priority for World Bank intervention has been defined as 'support for Government forest policies that will increase the area of Natural Reserves, National Parks and Protection Forests that are excluded from logging or other timber harvesting' (Spears and Dyson, 1988).

The counter-argument may be made that much of the remaining forest has already been harvested or disturbed in some way and is

Table 1. Uganda's principal medium-altitude forest reserves. Other forest reserves exist, but the 12 listed contain the largest remaining areas of medium-altitude forest

\begin{tabular}{lcc}
\hline Reserve & $\begin{array}{l}\text { Total area } \\
(\mathrm{sq} \mathrm{km})\end{array}$ & $\begin{array}{l}\text { Forested area } \\
\text { (sq km) }\end{array}$ \\
\hline 1. Budongo & 793 & 428 \\
2. Bugoma & 365 & 297 \\
3. Impenetrable (Bwindi) & 321 & $302 *$ \\
4. Itwara & 87 & 68 \\
5. Kalinzu-Maramagambo & 580 & 523 \\
6. Kasyoha-Kitomi & 399 & 328 \\
7. Kibale & 560 & 431 \\
8. Mabira & 306 & $280 *$ \\
9. Mgahinga & 29 & $20 *$ \\
10. Mount Elgon & 1145 & $230 *$ \\
11. Ruwenzori & 996 & $230 *$ \\
12. West Mengo & 728 & $460 * *$ \\
\hline
\end{tabular}

Numbers refer to Figure 1

* Principally montane or alpine vegetation

** Heavily degraded 
thus no longer natural. The conversion of natural forest in Uganda may be justified in any case since the resumption of timber exports has important potential as a foreign-exchange earner, of perhaps crucial importance to the country's nearly bankrupt economy.

As a requirement under the Wildlands Policy, a conservation component was included in the programme, with an initial budget of $\$ 200,000$ (0.6 per cent of the total). The World Bank Staff Appraisal report (1987) proposed an arbitrary division of the remaining natural forest area along the lines of recommendations made by UNESCO's Man and Biosphere programme: forests slated for economic utilization should contain reserved pristine areas, and the interface of the two should be protected by buffer zones. It was decided that at least 20 per cent of the remaining forest area should be set aside as totally protected Nature Reserves and at least 30 per cent as buffer zones. This component, along with all other aspects of natural forest rehabilitation, was subcontracted to the European Community (EC). On the advice of its staff, the amount of funds made available for conservation activities was increased considerably: a good start.

Possibilities for the protection of small areas as Sites of Special Scientific Interest (SSSIs, after the system employed by the British Nature Conservancy Council) have also been discussed. The forests outside areas allocated as SSSIs, nature reserves and buffer zones are to be managed for sustainable timber production, but the methods to be employed have yet to be defined.

The EC project may thus be regarded as fulfilling requirements of the Wildlands Policy and conforming to an international ethic of nature conservation. However, the total size of the remaining forests should perhaps be considered (Table 1). While total or partial preservation of at least 50 per cent of Amazonia might be applauded, is 50 per cent of the already critically reduced medium-altitude forest ecosystem a viable unit?

If harvested forest can be managed in a way that is sustainable in the long term, in the sense of sustaining the ecosystem as well as the timber yield, then the forests will certainly

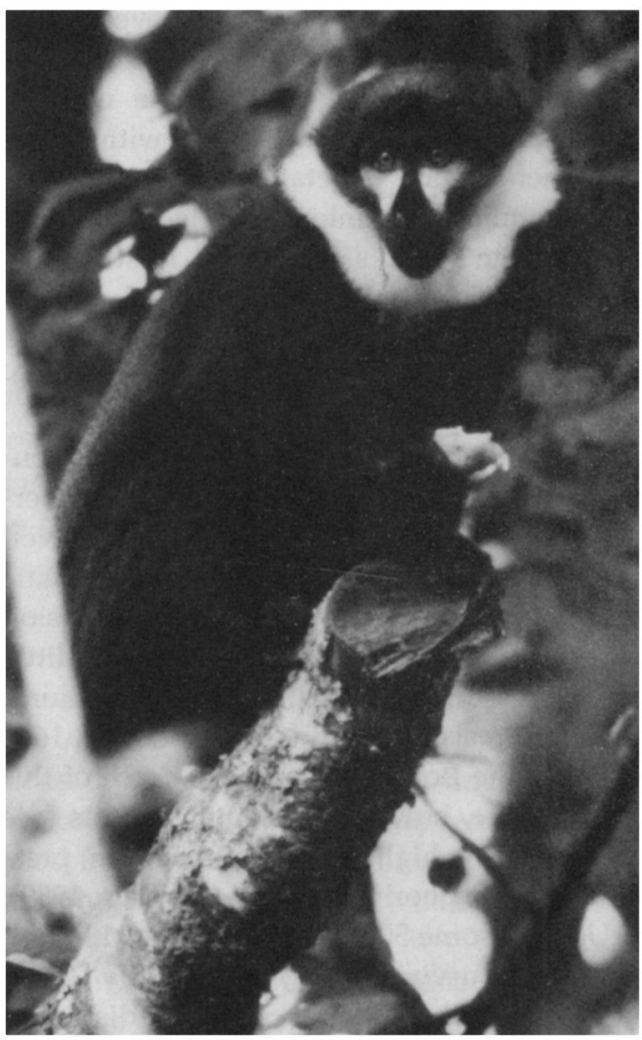

L'hoests monkey Cercopithecus lhoesti, one of up to nine higher primates found in medium-altitude forests (G. M. Tabor).

be no worse off than they were before the onset of the EC project (given problems of encroachment and illegal logging that have since been curtailed). While due credit should be given for effective preservation exercises, the viability of proposed management practices have yet to be determined. And have the decision makers duly considered other dollarearning ways of utilizing the remaining forest other than for timber production?

\section{The case for forest preservation}

Struhsaker (1987) summarized a number of alternate uses and values of natural forest, pointing out that forest policy often centres on only two out of many potential interest groups, namely the fuelwood/charcoal industry and the timber industry. Forests are too 


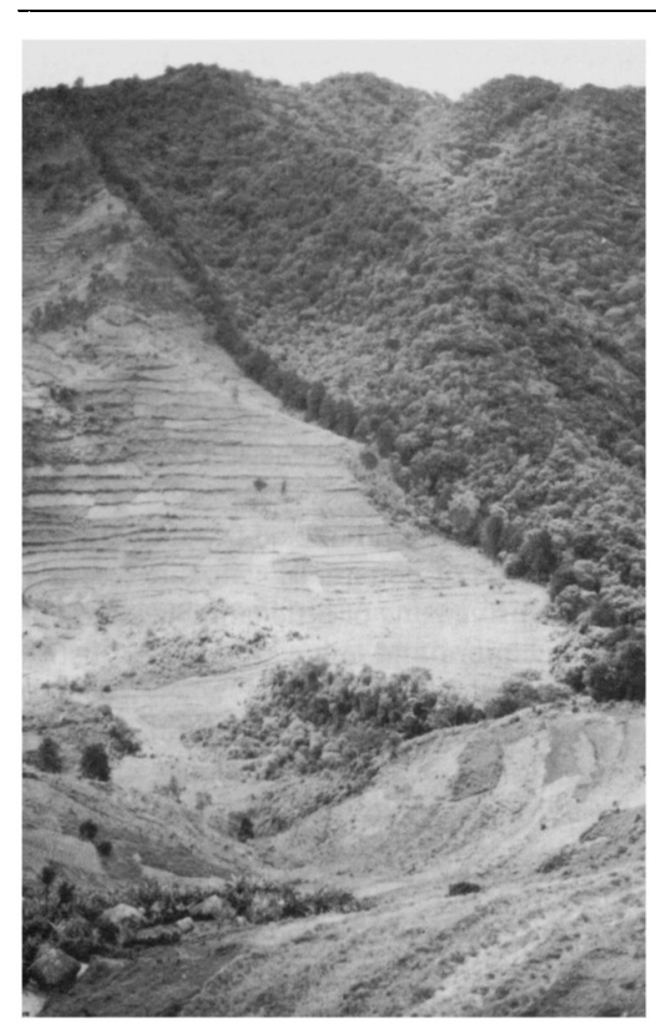

Visible land pressures: the boundary of the Impenetrable Forest Reserve (G. M. Tabor).

often forgotten in their roles as protectors of water supplies and soils, stabilizers of local climates, sources of food and medicines, and so on. Such factors do not fit easily into a cost-benefit analysis and can imply a timescale of benefits that is impossible for human developers to visualize (Leslie, 1987). Sawn timber has the benefit of being tangible and of considerable value in hard currency; charcoal is needed here and now. But should these take priority over all else? The case for the preservation of all or most of Uganda's remaining forests rests on two points; the unknown effects and possible unsustainability of forest management operations, and the largely unrecognized potential for tourism.

\section{Utilization or exploitation?}

The original World Bank programme, whose contents may not be divulged, is known not to have considered additional research a priority: adequate information was taken to be available from work carried out in the 1960s. Unfortunately, much cumulative information ceased to be collected during Uganda's political upheavals. Many written records were lost or destroyed. How, therefore, will decisions be made as to the form and procedures for sustainable management in the medium-altitude forests (given that no African country can reasonably claim to be practising sustainable management)?

Kasenene (1987), working in the Kibale Forest Reserve, found that mechanized selective felling, and particularly felling followed by poisoning of non-commercial species, failed to limit damage or to create suitably sized gaps for successful natural regeneration in the species-rich forests. Natural treefall gaps average $256 \mathrm{sq} \mathrm{m}$ in size: gaps in lightly and heavily logged forests average $467 \mathrm{sq} \mathrm{m}$ and $1307 \mathrm{sq} \mathrm{m}$, respectively. Seedling regeneration was poor when gaps averaged more than $650 \mathrm{sq} \mathrm{m}$ in size (which corresponded to felling levels of more than $17 \mathrm{cu} \mathrm{m} / \mathrm{ha}$ ).

Even after 20 years, the density of saplings and pole trees in heavily felled forests was only 45 per cent that of the stocking level of unlogged forest; heavily felled and treated forest had reached stocking levels only 27 per cent that of unlogged forest. Heavy felling also resulted in treefall levels nearly three times that of unlogged and lightly logged forest. This suggests that only a very low level of felling may provide for a sustainable forest management system, which according to Skorupa and Kasenene (1983) should mimic the natural rate of treefalls. Such a low-offtake forest management system is unlikely to be economically viable.

\section{Tourism}

Achievement of political stability in Uganda over the last few years has opened up a real new economic possibility for the medium-altitude forests: that of tourism The medium-altitude and montane forests of south-west Uganda hold perhaps the largest population of 
mountain gorillas Gorilla gorilla beringei left extant; a resource that is currently underdeveloped for tourism. Gorillas are concentrated in the montane forests, perhaps because of the destruction of much of the medium-altitude forests, but the medium-altitude forests that remain still contain the highest population densities of forest monkeys recorded anywhere in the world and many rare birds. With other attractions, such as Murchison Falls and the Ruwenzori Mountains, tourism in Uganda has enormous potential. International aid agencies are coming to regard tourism as perhaps the largest untapped foreign-exchange earner in Uganda, and forests could play an important role in its development. Wholesale extraction of timber and subsequent disruption of the forest ecosystem might be thought exceedingly short-sighted. Tourism was once a significant factor in Uganda's economy, second only to coffee as a foreign-exchange earner. It could become so again.

\section{Forested national parks}

Proposals have been put forward for the creation of forested national parks in Uganda. The areas so far being considered are the Ruwenzori Mountains, and the gorilla-populated Mgahinga and Impenetrable forests. Only the last contains a certain amount of medium-altitude forest. These areas could, in time, be supplemented by other potential tourist attractions such as the Kibale forest (which is entirely medium-altitude forest). Harvesting should, perhaps, be restricted to forests already badly damaged by past unsustainable forestry practices or by encroachment. In time, harvesting should, perhaps, be directed away from natural forests altogether and towards softwood or hardwood plantations created by the Forest Department outside of the existing protected forest areas.

\section{The case for forest conservation}

Many agencies concerned with environmental issues now support the broader definition of conservation, as defined under the World Conservation Strategy (IUCN, 1980), namely:

"The management of human use of genetic resources so that they may yield the greatest sustainable benefit to present generations, while maintaining their potential to meet the needs and aspirations of future generations.'

Conservation thus implies more than the narrow exclusivity that is often thought as the only way of ensuring the maintenance of tropical forest ecosystems (Roche, 1979). Given the pressures and problems facing the governments of developing nations, the setting aside of large areas of potentially valuable resource as an exclusive zone of little tangible benefit is becoming more and more difficult to justify. The solution lies in finding a compromise between environmental and economic needs.

\section{Multiple-use management}

The science of tropical forestry has developed a great deal over the last 20 years. It should now be possible to design management systems that are sustainable over the long term. Inappropriate or out-dated management practices, such as those examined by Kasenene (1987), can be dropped in favour of controlled pit-sawing or mobile saw-milling, and restocking/replanting exercises.

Sustainable off-take can be determined by monitoring of ecosystem processes as they affect timber stand regeneration. Sustainability may be defined as (after Wyatt-Smith, 1987):

'To exploit forest in such a way as to provide a regular yield of forest products without destroying or radically altering the composition and structure of the forest as a whole. Thus it is more than maintaining the rate of production at the low level of natural forest, which merely replenishes natural mortality. It is used in the sense of enhanced production through silvicultural practices whilst conserving the protective role of the vegetation and the genetic pool of all species.'

A multiple-use management system will involve harvesting of timber from some sectors of the forest estate but will also set aside buffer zones, where only minimal human use will be 
allowed, and nature reserves, where no destructive activities at all will be permitted.

Although not enough data are currently available to define a forest harvesting system that is ecologically and economically sustainable, some success has been achieved in Uganda. Certain forest plots harvested in the 1960s, replanted with native hardwoods of various species, and carefully managed thereafter, have developed a good second crop of timber (Earl, 1968; Plumptre and Earl, 1984). Although not fully investigated, these forest plots appear also to have maintained substantial wildlife populations.

The management system used in the 1960s can be refined somewhat in the light of current knowledge. The substantial off-take required to make timber harvesting an economically viable form of land use need not necessarily conflict with the needs of wildlife, if the forest is carefully managed. Trees and wildlife are part of the same system: foresters are aware of the fact that the first cannot exist in isolation. As an adjunct to the Natural Forest Management and Conservation Project of the EC, the Forest Department of Uganda is about to embark upon a major research project to determine precisely how an ecologically sustainable forest management system can be created.

The remaining large areas of medium-altitude forest in Uganda fall within forest reserves, each of which contains at least one nature reserve. These areas are set aside for the maintenance of timber tree seed stock and for the protection of wildlife. At present, the area of strictly protected nature reserves is being increased, and buffer zones are being established around them. There is some difference of opinion, referred to as the SLOSS argument (Single Large or Several Small), concerning the relative value of preserving a few large forest areas (as would be the case with forested national parks) or many smaller areas scattered over the country (as is the case with nature reserves within forest reserves). It is generally accepted that the latter preserves the greatest biological diversity, although the former may be better able to withstand aperiodic crises, such as droughts. However, sustainably managed forest reserves should, by definition, also maintain wildlife populations outside of nature-reserve areas, resulting in several larger conservation units (uncommonly the case these days).

Much of the debate that surrounds the value of national parks over areas administered by the Forest Department concerns the relative abilities of the different departments to protect areas under their jurisdiction. Under Ugandan law, the highest level of protection of an ecosystem is accorded by national-park status, and it is often assumed that delimitation of an area as a national park will better protect and preserve it. This may not always be the case. It relies upon the financial and other resources available to the department concerned. In Madagascar, for example, the highest level of preservation is accorded by the status of 'Strict Nature Reserve' (Reserve Naturelle Integrale). These areas are generally located within forest reserves and fall within the jurisdiction of the Forest Department of that country (IUCN, 1986). There is a precedent for the integration of forest preservation and management of the economic resource: these are all part of a sustainable forest management strategy.

The Forest Department of Uganda has plans to create a new unit of forest conservation, namely a 'Forest Park'. This is being written into law at present. A forest park will be a multiple-use unit, with provision for amenity use areas as well as strictly protected nature reserves and zones of sustainable harvesting. The Forest Department thus realizes the value of the forests for tourism and has already taken steps to provide for this demand upon the natural forests. There are a number of candidates for forest-park status, including the three areas proposed as national parks and the Kibale Forest Reserve.

\section{Summary}

The economic pressures currently faced by Uganda cannot be overlooked. The need for development in the face of Uganda's growing population must be addressed in terms of conservation policies and their sustainability. To 
establish the conservation ethic in the coming generations of Ugandans requires education and economic incentives. As time goes by, protected areas will be required to justify their existence in economic terms: only those that can do so will fend off competing land-use options.

There is a strong need in Uganda to promote economically viable uses of the forest estate, be it for sustainable timber production, harvesting of alternate forest products, tourism or whatever. Many of Uganda's foresters are becoming aware of their role in forest preservation, as well as their responsibility in ensuring effective utilization of the resource. The ultimate division of the forest estate into conservation units of whatever type will, of course, be decided by the Government of Uganda. Since the remaining area of forest estate is so small, it may be hoped that, over time, the focus of timber harvesting will shift from the natural forests to established plantations outside of the forest reserves. Over the next few years, which are crucial as far as the forests are concerned, it is likely that the Forest Department will fulfil their role as protectors of the resource.

\section{Acknowledgments}

Permission for the authors' work in Uganda was kindly granted by the National Research Council and Office of the President; financing was primarily from Wildlife Conservation International (New York Zoological Society) and Makerere University. We thank members of the Uganda Forest Department for useful discussion, in particular D. E. Earl, F. Kigenyi and B. Munyakabere. T. Butynski kindly offered comments on the manuscript.

\section{References}

Earl, D.E. 1968. Latest techniques in the treatment of natural high forest in the South Mengo District. Paper presented in Ninth Commonwealth Forestry Conference, India.

Hamilton, A.C. 1974. Distribution patterns of forest trees in Uganda and their historical significance. Vegetation, 29, 21-35.
Hamilton, A.C. 1984. Deforestation in Uganda. Oxford University Press, Nairobi, Kenya.

Huart, $d^{\prime}$ J.P. 1989. Bases for the development of a co-ordinated management of contiguous protected areas in Zaire and Uganda. Unpubl. report to the European Development Fund, Headquarters of the European Community, Brussels, Belgium.

IUCN. 1980. World Conservation Strategy. Ed. IUCN, UNDP and WWF. IUCN, Gland, Switzerland.

IUCN. 1986. IUCN Directory of Afrotropical Protected Areas. IUCN, Gland, Switzerland.

Kasenene, J.M. 1987. The influence of mechanized selective logging, felling intensity and gap-size on the regeneration of a tropical moist forest in the Kibale Forest Reserve, Uganda. Ph.D. dissertation, Michigan State University, E. Lansing, USA.

Ledec, G. and Goodland, R.J.A. 1987. Wildlands: their Protection and Management in Economic Development. The World Bank, Washington DC, USA.

Leslie, A.J. 1987. A second look at the economics of natural management systems in tropical mixed forests. Unasylva, 155 (39), 46-58.

Plumptre, R.A. and Earl, D.E. 1984. Integrating small industries with management of tropical forest for improved utilization and higher future productivity. Paper presented to IUFRO Meeting on Properties and Utilization of Tropical Timbers, Manaus, Brazil.

Roche, L. 1979. Forestry and the conservation of plants and animals in the tropics. Forest Ecol. Manage. 2, 103-122.

Skorupa, J.P. and Kasenene, J.M. 1983. Tropical forest management:can rates of natural treefalls help guide us? Oryx, 18, 96-101.

Spears, J. and Dyson, M. 1988. Options for World Bank Intervention to Protect Tropical Rainforests. The World Bank, Washington DC, USA.

Struhsaker, T.T. 1987. Forestry issues and conservation in Uganda. Biol. Cons. 39, 209-234.

World Bank. 1986. The World Bank's Operational Policy on Wildlands: their Protection and Management in Economic Development. The World Bank, Washington, DC, USA.

Wyatt-Smith, J. 1987. The management of tropical moist forest for the sustained production of timber. Report to IUCN/IIED/WWF. IIED, London.

G. M. Tabor, African Wildlife Foundation, P.O. Box 48177, Nairobi, Kenya.

A. D. Johns and J. M. Kasenene, Makerere University Biological Field Station, P.O. Box 10066, Kampala, Uganda. 